\title{
TINJAUAN PENDIDIKAN MENURUT PANDANGAN AL-GHAZALI
}

\author{
Eko Setiawan \\ Alumnus Pascasarjana Sosiologi Universitas Brawijaya Malang \\ e-mail: oke.setia@gmail.com
}

\begin{abstract}
Ghazali was a great scholar who pays considerable attention to education. Educational practices and the concept of education has been used extensively by the paedagog until today. This type of education that developed seemed to be influenced by views on sufism and jurisprudence. Educational concept put forward a systematic and comprehensive also consistently in line with the attitude and personality as a sufi. Al-Ghazali's concept of education is an application and a response from the answer to the social problems it faces today.
\end{abstract}

Keywords: education, Islam, al-Ghazali

\begin{abstract}
Abstrak: al-Ghazali adalah seorang ulama besar yang menaruh perhatian cukup besar terhadap pendidikan. Praktik pendidikan maupun konsep pendidikannya telah banyak dimanfaatkan oleh para paedagog sampai saat ini. Corak pendidikan yang dikembangkannya tampak dipengaruhi oleh pandangannya tentang tasawuf dan fiqih. Konsep pendidikan yang dikemukakannya sistematik dan komprehensif juga secara konsisten sejalan dengan sikap dan kepribadiannya sebagai seorang sufi. Konsep pendidikan al-Ghazali tersebut merupakan aplikasi dan respon dari jawaban terhadap permasalahan sosial kemasyarakatan yang dihadapinya saat ini.
\end{abstract}

Kata-Kata Kunci: pendidikan, Islam, al-Ghazali

\section{Pendahuluan}

Kata pendidikan tentunya sudah tidak asing lagi didengar, karena dalam kehidupan sehari-hari, bahkan seluruh kehidupan, manusia tidak dapat dipisahkan dengan pendidikan. Dunia pendidikan tidak akan pernah habis untuk dibicarakan. Karena dengan pendidikan, 
seseorang dapat mencapai kehidupan yang lebih baik dan mempunyai wawasan yang luas. Pendidikan bagi manusia merupakan kebutuhan mutlak yang harus dipenuhi sepanjang hayat. Tanpa pendidikan sama sekali, mustahil suatu kelompok manusia dapat hidup berkembang sejalan dengan cita-cita untuk maju, sejahtera dan bahagia menurut konsep pandangan hidup mereka. Bahkan, masalah pendidikan itu sama sekali tidak dapat dipisahkan dari kehidupan manusia, baik dalam kehidupan keluarga maupun dalam kehidupan berbangsa dan bernegara.

Pendidikan sebagai usaha membina dan mengembangkan pribadi manusia, aspek rohaniah, dan jasmaniah juga harus berlangsung secara bertahap. Oleh karena itu, suatu kematangan yang bertitik akhir pada optimalisasi perkembangan atau pertumbuhan, baru dapat tercapai bilamana berlangsung melalui proses demi proses ke arah tujuan akhir perkembangan atau pertumbuhan (Arifin, 2005: 12). Dengan demikian, pendidikan dipandang sebagai usaha sadar yang bertujuan dan usaha mendewasakan setiap individu sehingga dapat hidup secara optimal, baik sebagai pribadi maupun sebagai bagian dari masyarakat, serta memiliki nilai-nilai moral dan sosial sebagai pedoman hidupnya (Sudjana, 1991:2).

Pendidikan merupakan proses yang bertumpu pada tujuan. Pendidikan yang dimaksud adalah usaha untuk melestarikan dan mengalihkan serta mentransformasikan nilai-nilai kebudayaan dalam segala aspek dan jenisnya kepada generasi penerus. Jadi pendidikan Islam itu tidak hanya memperhatikan satu aspek saja, tetapi segala aspek yang ada, meliputi aspek jasmani, rohani, dan akal pikiran serta akhlaq. Oleh karena itu, setiap proses pendidikan yang akan dilaksanakan harus memperhatikan beberapa hal. Harapan tercapainya sebuah keberhasilan dalam suatu aktifitas pendidikan Islam dalam mencapai tujuan yang dirumuskan, banyak dipengaruhi oleh beberapa faktor antara lain: faktor tujuan, faktor pendidik, faktor anak didik, faktor alat dan metode, dan faktor lingkungan. Di antara kelima faktor tersebut tidak bisa lepas satu sama lain, di dalam prosesnya saling berkaitan erat sehingga membentuk satu sistem yang saling mempengaruhi. 
Berbicara mengenai pendidikan, maka tidak seharusnya meninggalkan tokoh muslim yang satu ini, yaitu Imam al-Ghazali. Ia merupakan seorang ulama besar dan sekaligus ahli pendidikan. Praktik pendidikan maupun konsep pendidikannya telah banyak dimanfaatkan oleh para paedagog sampai saat ini. Baik ilmuwan Barat maupun Timur semua mengenal al-Ghazali. Ketenaran al- Ghazali bukan tanpa alasan. Kehadirannya banyak memberikan khazanah bagi kehidupan manusia. Sosok figur al-Ghazali sebagai pengembara ilmu yang sarat pengalaman mengantarkan posisinya menjadi personifikasi di segala bidang dan di setiap zaman (Zaqzuq, 1987: 29). Kegigihannya dalam menelusuri kebenaran dan ilmu yang bermodalkan otak brilian (cemerlang), sarat dengan ciri keutamaan sekaligus kecendekiawanannya menjadikan dirinya pantas menyandang gelar sebagai alim/ilmuwan sejati. Al-Ghazali dikenal sebagai ilmuwan yang konsekuen, kedalaman dan keluasan ilmunya tidak membuatnya congkak dan sombong apalagi gegabah bertindak. Setumpuk kelebihan yang ia miliki justru mengilhami pribadinya semakin "tawadhu" dan "taqarrub" pada Tuhan penguasa alam yang maha dalam segala hal (Abidin, 1998: 41).

Dalam hal itu, filsafat al-Ghazali tentang pendidikan merupakan interpretasi yang luas dan lengkap bersumberkan dari ajaran agama Islam. Al-Ghazali malahan memiliki keistimewaan tentang teori pendidikan yang dimajukannya, yakni menyatupadukan kepentingankepentingan jasmani, akal dan rohani, ilmiah dan jiwa agama. Sayang berbagai pandangan dan teori pendidikan al-Ghazali yang luas itu tidak terhimpun dalam suatu karya/kitab an sich, tetapi tersebar dalam berbagai kitabnya yang membahas banyak bidang garapan (Qardhawi, 1997: 91). Setiap kitab yang dihasilkannya memang tidak dispesifikasikan untuk membahas pendidikan, namun di setiap produk karyanya itu selalu menyentuh aspek pendidikan.

Dari sini, penulis tertarik untuk mengkaji lebih dalam tentang tinjauan pendidikan menurut pandangan al-Ghazali. Pada tulisan ini, pembahasan akan difokuskan pada pemikiran al-Ghazali tentang pendidikan, tujuan pendidikan, subjek didik, kurikulum pendidikan, metode pendidikan, evaluasi pendidikan, dan relevansi pemikiran alGhazali dengan pendidikan saat ini. Ada beberapa alasan yang 
mendorong penulis untuk memilih judul tersebut, diantaranya adalah: (1) Pendidikan menurut al-Ghazali adalah tugas yang harus di laksanakan dengan sebaik-baiknya. Pendidikan adalah tugas yang sangat mulia dan utama dari semua pekerjaan yang dapat dilakukan oleh manusia. Sebab hanya dengan pendidikan dan pengajaranlah manusia dapat mendekatkan diri kepada Allah SWT; (2) Pendidikan menurut pandangan al-Ghazali termasuk ibadah dan sarana perbaikan sosial, sehingga dapat ditempuh melalui pendidikan dan pengajaran yang benar.

\section{Biografi al-Ghazali}

Al-Ghazali bernama lengkap Abu Hamid Muhammad ibn Muhammad ibn Muhammad al-Tusi al-Ghazali, ia lahir di Tus, kini dekat Masyhad, Khurasan, tahun $450 \mathrm{H}$ atau $1058 \mathrm{M}$, dari ayah seorang penenun wool (ghazzâl) sehingga dijuluki "al-Ghazali" (Soleh, 2009:18). Sang ayah ingin sekali al-Ghazali tumbuh di lingkungan yang Islami. Karena itu sebelum wafatnya ia menitipkan al-Ghazali dan adiknya kepada seorang temannya yang sufi dan menyerahkan biaya hidup untuk mereka berdua (Daudy, 1989: 97). Sang sufi adalah seorang yang miskin. Karena itu ketika biaya hidupnya habis, maka ia menyerahkan keduanya ke salah satu sekolah yang didirikan oleh Nizham al-Mulk yang dapat menyediakan asrama dan biaya hidup bagi pelajar. Beliau wafat di Tabristan wilayah Provinsi Thus pada tanggal 11 Jumadil Akhir $505 \mathrm{H}$ bertepatan dengan 1 Desember $1111 \mathrm{M}$. AlGhazali pada masa kanak-kanak belajar fikih kepada Ahmad ibn Muhammad al-Radzakani, kemudian beliau pergi ke Jurjan berguru kepada Imam Abu Nushr al-Ismaili Thus (Nata, 2000: 82). Selanjutnya ia pergi ke Naisabur dan berguru kepada Abu al-Ma'ali al-Juwaini (Imam al-Haramain) di Madrasah Nizhamiyah, mempelajari ilmu-ilmu fikih, ushul fikih, dan mantiq serta tasawuf pada Abu Ali al-Faramadi (Ramayulis, 2005: 3). Dengan kecerdasan dan kemauan belajarnya yang luar biasa serta kemampuannya dalam mendebat segala sesuatu yang tidak sesuai dengan penalaran yang jernih, al-Juwaini kemudian memberikan predikat bahrun mughrîq "laut yang dalam nan menenggelamkan" (Nizar, 2002: 87). Dari Naisabur, al-Ghazali menuju Baghdad dan menjadi guru besar di Madrasah Nizhamiyah yang 
didirikan oleh perdana menteri Nizham al-Mulk. Di tengah-tengah kesibukannya di Madrasah Nizhamiyah, ternyata ia tidak melupakan dunia jurnalistik (Al-Rasyidi, 2005: 86).

Karena keahliannya di berbagai bidang keilmuan, ia memperoleh

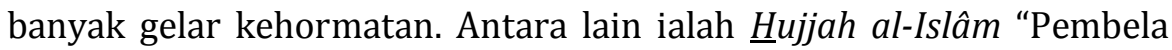
Islam", Zainuddîn "Hiasan Agama", Bahrun Mughrîq "Samudra yang Menenggelamkan", Syaikh al-Shûffiyyîn "Guru Besar para Sufi", dan sebagainya (Kurniawan, 2011: 88). Ia menulis lebih dari 70 buku, yang terbesar di antaranya adalah Keruntuhan Para Filosuf (Tahâffut alFalâsifah) yang mendorong Ibnu Rusyd menulis buku besar untuk membantah pendapat al-Ghazali yang berjudul Runtuhnya Keruntuhan (Tahâfut Tahâffut al-Falâsifah). Karya besarnya berjudul Fâtihah alUlûm (Introduction to the Sciences), berisi tentang beberapa pandangan mengenai persoalan-persoalan pendidikan, merupakan penyempurnaan terhadap ilmu pendidikan Eropa pada masa itu, yang sesungguhnya dapat dibandingkan dengan konsep-konsep pendidikan modern (Nakosteen, 1996: 126).

Keunggulan ilmu al-Ghazali membuatnya menjadi sangat tersohor sehingga pada tahun $484 \mathrm{H}$ (1091 M), ia diangkat menjadi ustadz (dosen) pada Universitas Nidhamiyah di Baghdad. Setahun setelah ia berusia 34 tahun, al-Ghazali diangkat menjadi pimpinan (rektor) pada universitas tersebut karena prestasinya yang begitu luar biasa. Selama menjadi rektor, al-Ghazali banyak menulis buku di bidang fikih, ilmu kalam, dan buku-buku sanggahan terhadap aliranaliran kebatinan, ismailiyah, dan filsafat. Setelah 4 tahun menjadi rektor di universitas tersebut, ia mengalami krisis keraguan yang meliputi akidah dan semua jenis ma'rifat. Kemudian ia melanglang buana antara Syam, Baitul Maqdis, dan Hijaz selama kurang lebih sepuluh tahun dan menghabiskan waktunya untuk khalwat, ibadah, i'tikaf, dan menjalankan ibadah haji serta berziarah ke makam nabinabi. Setelah dibujuk untuk kembali mengajar di universitasnya, akhirnya al-Ghazali kembali menjadi dosen pada tahun 499 H (1106 M). Tetapi, tidak lama setelah itu, ia kembali ke tempat asalnya di desa Thus dan menghabiskan sisa umurnya untuk membaca al-Qur'an dan hadis serta mengajar. Di samping rumahnya, al-Ghazali mendirikan madrasah untuk para santri yang mengaji dan sebagai tempat 
berkhalwat bagi para sufi. Al-Ghazali tutup usia pada tahun $505 \mathrm{H}$ (1111 M) yaitu pada umur 55 tahun (Abdullah, 2002: 28).

\section{Pemikiran al-Ghazali tentang Pendidikan}

Imam al-Ghazali menegaskan bahwa tinggi-rendahnya kehidupan manusia sangat ditentukan oleh sifat penguasaan ilmu pengetahuan. Kewajiban utama manusia dalam pendidikan dan penggalian ilmu pengetahuan adalah tentang dzat Allah Yang Maha mutlak. Karena kebenaran ilmu pengetahuan sifatnya nisbi, pertamatama harus diketahui tentang kebenaran mutlak yang hanya milik Allah. Pengetahuan dalam bentuk apapun tidak akan sampai pada kebenaran mutlak karena ilmu bersumber dari Yang Maha Mutlak, yakni Rabb al-'Âlamîn. Al-Ghazali membagi metode perolehan ilmu menjadi dua, yaitu metode pengajaran manusia dan pengajaran dari Tuhan. Metode pengajaran manusia merupakan metode yang biasa dilakukan di sekolah formal dan non formal, yang mengandalkan komunikasi interpersonal dan interaksi sosial. Metode pengajaran dari Tuhan merupakan metode pengajaran yang melibatkan komunikasi manusia dengan Allah (Basri, 2009: 223).

Dalam memahami pemikiran al-Ghazali, tentunya harus dilakukan banyak kajian terhadap literatur yang mengupas riwayat hidupnya maupun karya-karyanya yang sangat monumental dalam berbagai disiplin ilmu. Berkaitan dengan profesinya sebagai pemikir, al-Ghazali telah mengkaji secara mendalam dan kronologis minimal empat disiplin ilmu sehingga ia menjadi ahli ilmu kalam atau teolog, filosof, seorang sufi karena ilmu tasawufnya, dan juga seorang yang anti ilmu kebatinan. Pandangan al-Ghazali yang sangat terkenal adalah pandangannya tentang hakekat manusia, yang berlandaskan pada esensi manusia yaitu jiwanya yang bersifat kekal dan tidak hancur. Ada empat istilah yang sangat populer dikemukakan oleh al-Ghazali dalam pembahasannya yang begitu mendalam tentang esensi manusia, yaitu tentang hati (qalb), ruh, jiwa (nafs), dan akal (aql).

Mengenai tujuan hidup manusia, al-Ghazali menyatakan bahwa: "Segala tujuan manusia itu terkumpul dalam agama dan dunia. Agama tidak terorganisasikan selain dengan terorganisasinya dunia. Dunia adalah tempat bercocok tanam bagi akhirat. Dunia adalah alat yang 
menyampaikan kepada Allah bagi orang yang mau memperbuatnya menjadi tempat tetap dan tanah air abadi." Dari pernyataannya tersebut dapat disimpulkan bahwa manusia memiliki dua tujuan hidup. Yang pertama adalah sebagai wakil Allah di dunia untuk melaksanakan kehendak-Nya atau tujuan duniawi. Yang kedua adalah tujuan akhirat, yaitu mendapatkan kenikmatan surgawi yang berpuncak saat manusia dapat bertemu Penciptanya.

Dalam bidang pendidikan dan pengajaran, al-Ghazali banyak mencurahkan perhatian dan analisisnya terhadap esensi manusia mendasari pemikirannya pada kedua bidang ini. Menurut al-Ghazali, manusia dapat memperoleh derajat atau kedudukan yang paling terhormat di antara sekian banyak makhluk di permukaan bumi dan langit karena ilmu dan amalnya. Sesuai dengan pandangan al-Ghazali terhadap manusia dan amaliahnya, yaitu bahwa amaliah itu tidak akan muncul dan kemunculannya hanya akan bermakna kecuali setelah ada pengetahuan. Sehingga wajar bila dalam karyanya yang sangat monumental, Ihyâ Ulûmiddîn, al-Ghazali mengupas ilmu pengetahuan secara panjang lebar dalam sebuah bab tersendiri. Dalam pembahasannya tentang ilmu, al-Ghazali menggambarkannya dalam tatanan sosial masyarakat, dalam artian bahwa sebuah ilmu atau profesi tertentu diperlukan untuk melaksanakan kegiatan-kegiatan yang diwajibkan dalam tatanan tersebut. Secara terperinci, ia menggunakan pendekatan epistemologi, ontologi, dan aksiologi.

Ditilik dari bab pertama dalam kitab Ihyâ Ulûmiddîn, al-Ghazali adalah penganut kesetaraan dalam dunia pendidikan, ia tidak membedakan kelamin penuntut ilmu, juga tidak pula dari golongan mana ia berasal. Selama dia Islam maka hukumnya wajib, tidak terkecuali siapapun. Ia juga termasuk penganut konsep pendidikan tabula rasa (kertas putih) dan pendidikan bisa mewarnainya dengan hal-hal yang benar.

\section{Tujuan Pendidikan}

Menurut al-Ghazali, pendidikan dalam prosesnya haruslah mengarah kepada pendekatan diri kepada Allah dan kesempurnaan insani, mengarahkan manusia untuk mencapai tujuan hidupnya yaitu 
kebahagiaan di dunia dan akhirat. Sehingga tujuan pendidikan dirumuskan sebagai pendekatan diri kepada Allah, yaitu untuk membentuk manusia yang soleh, yang mampu melaksanakan kewajiban-kewajibannya kepada Allah dan kewajiban-kewajibannya kepada manusia sebagai hambaNya. Pendidikan merupakan suatu proses di mana suatu bangsa mempersiapkan generasi mudanya untuk menjalankan kehidupan dan untuk memenuhi tujuan hidup secara efektif dan efisien (Azra, 1998: 3). Selain mewariskan nilai-nilai budaya dari generasi ke generasi untuk memelihara identitas masyarakat, pendidikan juga bertugas mengembangkan potensi manusia untuk dirinya sendiri dan masyarakatnya (Shihab, 2008: 152).

Tujuan pendidikan jangka panjang yang dirumuskan sebagai pendekatan diri kepada Allah, dapat dicapai dengan melaksanakan ibadah wajib dan sunnah serta mengkaji ilmu-ilmu fardhu 'ain seperti ilmu syariah. Sementara orang-orang yang hanya menekuni ilmu fardhu kifayah sehingga memperoleh profesi-profesi tertentu dan akhirnya mampu melaksanakan tugas-tugas keduniaan dengan hasil yang optimal sekalipun, tetapi tidak disertai dengan hidâyah al-dîn, maka orang tersebut tidak akan semakin dekat dengan Allah.

Tujuan pendidikan jangka pendek menurut al-Ghazali adalah diraihnya profesi manusia sesuai dengan bakat dan kemampuannya dengan mengembangkan ilmu pengetahuan yang fardhu 'ain dan fardhu kifayah. Masalah kemuliaan duniawi bukanlah tujuan dasar dari seseorang yang melibatkan diri dalam dunia pendidikan. Seorang penuntut ilmu seperti siswa, mahasiswa, guru, atau dosen, akan memperoleh derajat, pangkat, dan segala macam kemuliaan lain yang berupa pujian, popularitas, dan sanjungan manakala ia benar-benar mempunyai motivasi hendak meningkatkan kualitas dirinya melalui ilmu pengetahuan untuk diamalkan. Sebab itulah, al-Ghazali menegaskan bahwa langkah awal seseorang dalam proses pembelajaran adalah untuk menyucikan jiwa dari kerendahan budi dan sifat-sifat tercela, dan motivasi pertama adalah untuk menghidupkan syariat dan misi Rasulullah. Tujuan pendidikan yang dirumuskan oleh al-Ghazali tersebut dipengaruhi oleh ilmu tasawuf yang dikuasainya, karena ajaran tasawuf memandang dunia ini bukan merupakan hal utama yang harus didewakan, tidak abadi dan akan 
rusak, sedangkan maut dapat memutuskan kenikmatannya setiap saat (Ramayulis. 2005: 5).

Al-Ghazali membagi tujuan pendidikan menjadi dua, yaitu:

a. Tujuan Jangka Panjang

Tujuan pendidikan jangka panjang ialah pendekatan diri kepada Allah. Pendidikan dalam prosesnya harus mengarahkan manusia menuju pengenalan, kemudian pendekatan diri kepada Tuhan pencipta alam.

b. Tujuan Jangka Pendek

Tujuan pendidikan jangka pendek ialah diraihnya profesi manusia sesuai dengan bakat dan kemampuannya.

Pemikiran al-Ghazali terhadap pendidikan tidaklah mengabaikan keseimbangan antara dunia dan akhirat. Hal ini dapat dilihat dari tujuan pendidikannya, yaitu agar manusia berilmu, bukan sekedar berilmu, melainkan ilmu yang diamalkan dalam kehidupan sehari-hari. Mempelajari ilmu pengetahuan tidaklah semata-mata untuk ilmu pengetahuan itu sendiri, tetapi sebagai wujud ibadah kepada Allah. Hal ini juga yang menjadi tujuan pendidikan Islam saat ini. Intinya, pendidikan menurut al-Ghazali bertujuan untuk mendekatkan diri kepada Allah SWT, sebagaimana tujuan penciptaan manusia yang termaktub dalam QS. Al-Dzariyat: 56 (Suwito, 2005: 83).

\section{Subjek Didik}

Dalam pandangan al-Ghazali, pendidik merupakan orang yang berusaha membimbing, meningkatkan, menyempurnakan dan menyucikan hati sehingga menjadi dekat dengan khâliqnya. Ia juga memberikan perhatian yang sangat besar pada tugas dan kedudukan seorang pendidik. Hal ini tercermin dalam tulisannya: "Sebaik-baik ikhwalnya adalah yang dikatakan berupa ilmu pengetahuan. Hal itulah yang dianggap keagungan dalam kerajaan langit. Tidak selayaknya ia menjadi seperti jarum yang memberi pakaian kepada orang lain sementara dirinya telanjang, atau seperti sumbu lampu yang menerangi yang lain sementara dirinya terbakar. Maka, barang siapa yang memikul beban pengajaran, maka sesungguhnya ia telah memikul perkara yang besar, sehingga haruslah ia menjaga etika dan tugasnya“ (Nata, 2000: 35). 
Dalam pembahasan mengenai pendidikan, manusia yang bergantung disebut murid dan yang menjadi tempat bergantung disebut guru, sehingga keduanya disebut sebagai subjek didik. Seseorang dinamai guru apabila memberitahukan sesuatu kepada siapapun. Seorang guru adalah orang yang ditugaskan di suatu lembaga untuk memberikan ilmu pengetahuan kepada para pelajar dan pada gilirannya dia memperoleh upah atau honorarium. Seorang guru atau ulama adalah orang yang menempatkan cita-cita teragung dan termulia tersebut di depan muridnya (Ali, 2005: 62).

Al-Ghazali sangat mengagungkan posisi guru di atas segalanya sebagaimana ungkapannya bahwa hak guru atas muridnya lebih agung dibandingkan hak orang tua atas anaknya karena orang tua hanya penyebab keberadaan anaknya di alam fana dan guru lah penyebab hidupnya yang kekal. Ia juga menambahkan bahwa makhluk yang paling mulia di muka bumi adalah manusia, sedangkan yang paling mulia penampilannya ialah kalbunya, guru atau pengajar selalu menyempurnakan, mengagungkan, dan menyucikan kalbu itu serta menuntunnya untuk dekat kepada Allah.

Berkaitan dengan tugas dan tanggung jawab guru profesional, alGhazali menyebutkan beberapa hal sebagai berikut:

1) Guru adalah orang tua kedua bagi murid

2) Guru adalah pewaris ilmu nabi

3) Guru adalah penunjuk jalan dan pembimbing keagamaan murid

4) Guru adalah sentral figur bagi murid

5) Guru adalah motivator bagi murid

6) Guru adalah seseorang yang memahami tingkat perkembangan intelektual murid

7) Guru sebagai teladan bagi murid

Pendapat al-Ghazali tentang hal ini adalah bagaimana seorang guru harus bersikap lemah lembut dan penuh kasih sayang pada murid selayaknya mereka adalah anak kandung sendiri (Kurniawan, 2003: 35). Selanjutnya, al-Ghazali menguraikan hal-hal yang harus dipenuhi murid dalam proses belajar mengajar sebagaimana berikut:

1) Belajar merupakan proses jiwa

2) Belajar menuntut konsentrasi

3) Belajar harus didasari sikap tawadhu 
4) Belajar bertukar pendapat hendaklah telah mantap pengetahuan dasarnya

5) Belajar harus mengetahui nilai dan tujuan ilmu pengetahuan yang dipelajari

6) Belajar secara bertahap

7) Belajar tujuannya adalah untuk berakhlakul karimah

Dengan tugas dan kewajiban tersebut diharapkan seorang peserta didik mampu untuk menyerap ilmu pengetahuan untuk mendekatkan diri kepada Allah swt. Dari uraian tersebut, menurut penulis artinya bahwa dalam pelaksanaan pendidikan, akhlak, moral maupun budi pekerti dari seorang peserta didik mendapatkan perhatian yang sangat besar. Walaupun demikian, beberapa tahun belakangan ini, di Indonesia khususnya, terjadi dekadensi moral oleh para peserta didik, sehingga untuk saat ini dirasa perlu untuk diterapkannya pendidikan karakter yang sebenarnya konsep ini sudah ada jauh sebelumnya.

\section{Kurikulum Pendidikan}

Kurikulum, dalam pengertian sederhana berarti mata pelajaran yang diberikan kepada anak didik untuk menanamkan sejumlah pengetahuan agar mampu beradaptasi dengan lingkungannya (Suwito, 2005: 84). Adapun mengenai materi pendidikan, al-Ghazali berpendapat bahwa al-Quran beserta kandungannya merupakan ilmu pengetahuan. Isinya sangat bermanfaat bagi kehidupan, membersihkan jiwa, memperindah akhlak, dan mendekatkan diri kepada Allah. Pandangan al-Ghazali tentang kurikulum dapat dipahami dari pandangannya mengenai ilmu pengetahuan. Ia membagi ilmu pengetahuan kepada yang terlarang dan yang wajib dipelajari oleh anak didik menjadi tiga kelompok, yaitu:

1. Ilmu yang tercela, banyak atau sedikit. Ilmu ini tidak ada manfaatnya bagi manusia di dunia dan di akhirat.

2. Ilmu yang terpuji, banyak atau sedikit. Ilmu ini akan membawa seseorang kepada jiwa yang suci bersih dan mendekatkan diri kepada Allah swt. 
3. Ilmu yang terpuji pada taraf tertentu, yang tidak boleh diperdalam, karena ini dapat membawa kegoncangan iman dan meniadakan Tuhan seperti ilmu filsafat.

Yang dimaksud dari kategorisasi ketiga ilmu tersebut adalah sebagai berikut: pertama, ilmu-ilmu tercela. Yang termasuk ilmu ini dalam pandangan al-Ghazali ialah ilmu yang tidak ada manfaatnya baik dunia maupun akhirat dan terkadang hanya membawa madharat bagi orang yang memilikinya ataupun bagi orang lain. Ilmu sihir misalnya dapat memisahkan persahabatan antar sesama manusia, menimbulkan dendam, permusuhan dan kejahatan. Sementara ilmu nujum menurut al-Ghazali dapat dibagi menjadi dua, yaitu ilmu nujum berdasarkan perhitungan ( $\underline{\text { hisâb) }}$, dan ilmu nujum berdasarkan istidlâly. Tapi beliau masih memberi toleransi dengan mengatakan seperlunya saja demi kebaikan, seperti ilmu nujum untuk mengetahui letak kiblat (Nata, 2000: 89). Kedua, ilmu-ilmu terpuji. al-Ghazali menjelaskan bahwa ilmu ini ialah ilmu-ilmu yang erat kaitannya dengan peribadatan dan macam-macamnya. Ia membagi jenis ilmu ini menjadi dua bagian, yaitu: yang fardlu 'ain, yaitu ilmu agama dengan segala jenisnya, mulai dari kitab Allah, ibadah pokok, hingga ilmu syari'at yang dengannya ia akan paham apa yang harus ditinggalkan dan apa yang harus dilakukan. Sedangkan yang fardlu kifayah adalah semua ilmu yang tidak mungkin diabaikan untuk kelancaran semua urusan, seperti ilmu kedokteran, ilmu hitung. Menurutnya, jika tidak ada yang mempelajari ilmu itu maka berdosalah seluruhnya, tetapi jika telah ada seseorang yang menguasainya dan dapat mempraktikkannya maka tuntutan wajibnyapun telah lepas dari yang lain. Ketiga, ilmu-ilmu yang terpuji dalam kadar tertentu atau sedikit, dan tercela jika mempelajarinya secara mendalam, karena dengan mempelajarinya dapat menyebabkan terjadinya kekacauan antara keyakinan dan keraguan yang dapat membawa pada kekafiran, seperti ilmu filsafat. Ilmu ini tidaklah wajib bagi setiap orang, karena menurut tabiatnya tidak semua orang dapat mempelajari ilmu itu dengan baik. Ia berpendapat bahwa orang yang mempelajari ilmu tersebut bagai anak kecil yang masih menyusu, dan akan sakit apabila diberikan makanan yang bermacam-macam yang belum dapat dicerna oleh perutnya. 
Dengan demikian, dapat dipahami bahwa pada prinsipnya, alGhazali lebih menekankan pada muatan ilmu-ilmu keagamaan dengan segala cabangnya dan juga ilmu-ilmu yang erat kaitannya dengan kemaslahatan manusia pada umumnya. Sehingga menurut al-Ghazali, selayaknya seorang pelajar pemula mempelajari ilmu agama asasi terlebih dahulu sebelum mempelajari ilmu furu'. Ilmu kedokteran, matematika dan ilmu terapan lain harus mengalah pada ilmu agama dalam pandangannya, karena ilmu agama meliputi keselamatan di akhirat, sedangkan yang terapan hanya untuk keselamatan di dunia. Ia juga lebih menekankan pada segi pemanfaatan ilmu pengetahuan dengan berdasarkan pada tujuan iman dan taqarrub pada Allah SWT. Hal ini menjadi wajar dengan melihat latar belakang kehidupan beliau sebagai seorang sufi.

\section{Metode Pendidikan}

Dalam hal yang berhubungan dengan metode pendidikan Islam, al-Ghazali menekankan pentingnya bimbingan dan pembisaaan. Dalam menerapkan metode tersebut al-Ghazali menyarankan agar tujuan utama dari penggunaan metode tersebut diselaraskan dengan tingkat usia, tingkat kecerdasan, bakat dan pembawaan anak dan tujuannya tidak lepas dari hubungannya dengan nilai manfaat. Oleh karena itu dalam metode pendidikannya ini, al-Ghazali cenderung mendasarkan pemikirannya pada prinsip ajaran sufi (penyucian jiwa) dan pragmatis (nilai guna).

Dalam uraiannya yang lain, al-Ghazali juga meletakkan prinsip metode pendidikan pada aspek mental atau sikap, sebagaimana katakata beliau "wajib atas para murid untuk membersihkan jiwanya dari kerendahan akhlak dan dari sifat-sifatnya yang tercela, karena bersihnya jiwa dan baiknya akhlak menjadi azas bagi kemajuan ilmu yang dituntutnya."

Dan hal tersebut dapat digunakan dengan menggunakan berbagai macam metode antara lain: metode keteladanan, metode bimbingan dan penyuluhan, metode cerita, metode motivasi, dan sebagainya. Selain itu, menurut al-Ghazali, dalam metode pendidikan ini ada dua macam kecenderungan yaitu: 
1. Kecenderungan religius sofistis, yang meletakkan ilmu-ilmu agama di atas pemikirannya. Dan melihatnya sebagai alat untuk menyucikan jiwa dan membersihkannya dari kotoran duniawi. Dengan demikian, ia menekankan kepentingan akhirat yang menurutnya harus dikaitkan dengan pendidikan agama.

2. Kecenderungan aktualitas manfaat yang tampak dari tulisantulisannya meskipun ia seorang sufi dan tidak suka kepada duniawi, namun dia mengulangi penilaiannya terhadap ilmu-ilmu menurut kegunaanya bagi manusia baik di dunia maupun di akhiratnya.

Metode-metode ini masihlah relevan untuk pendidikan saat ini, sebagaimana masih efektifnya metode hukuman dan pujian bagi peserta didik dalam proses pembelajaran. Walaupun demikian, pemberian hukuman ataupun pujian haruslah diberikan sesuai dengan kadarnya. Selain itu, sekarang ini sudah banyak lagi metode yang muncul sehingga pembelajaran akan lebih variatif dan tidak membosankan (Kurniawan, 2011: 92).

\section{Evaluasi Pendidikan}

Dalam bahasa Arab, kata yang paling dekat dengan kata evaluasi adalah muhâsabah, yang berarti menghitung atau memperkirakan. AlGhazali menggunakan kata tersebut dalam menjelaskan tentang evaluasi diri setelah melakukan aktivitas. Surat al-Hasyr ayat 18 dijadikan landasan berpijak oleh al-Ghazali dalam menguraikan tentang evaluasi diri, sebagaimana dikutip dalam karyanya (Umam, 1996:76). Sehingga dapat dirumuskan bahwa pengertian evaluasi adalah suatu usaha memikirkan, memperkirakan, membandingkan, menimbang, mengukur, dan menghitung aktivitas diri dan orang lain yang telah dikerjakan terkait dengan tujuan yang telah dicanangkan untuk meningkatkan usaha dan aktivitas menuju tujuan yang lebih baik di waktu mendatang. Subjek evaluasi yang terlibat dalam proses kependidikan tersebut dapat meliputi pimpinan lembaga, subjek didik, wali murid, dan tenaga administrasi.

Tujuan evaluasi secara umum, sebagaimana kutipan sabda Nabi yang dikutip oleh al-Ghazali, adalah sebagai berikut: "Jika kau telah merencanakan suatu pekerjaan atau suatu program kerja, maka pikirkanlah akibat atau hasil akhirnya. Jika kemungkinan benar 
(menguntungkan) maka teruskan, tapi jika kemungkinan sesat (merugikan) maka hentikan rencana itu."

Sehingga tujuan dari evaluasi pendidikan dapat dirumuskan sebagai suatu upaya untuk mengontrol efektivitas dan efisiensi usaha dan sarana, mengetahui segi-segi yang mendukung dan menghambat jalannya proses kependidikan menuju tujuan. Segi-segi yang mendukung dikembangkan, dan segi-segi yang menghambat diperbaiki atau diganti dengan usaha atau sarana lain yang lebih menguntungkan. Sebagaimana sabda Nabi yang dikutip oleh al-Ghazali yang ,menyatakan bahwa aktivitas kependidikan dalam satuan waktu yang telah ditentukan secara periodik, seperempat dari satuan waktu tersebut digunakan untuk mengadakan evaluasi: "Seyogyanya bagi orang yang berakal mempunyai empat bagian waktu, dan satu bagian waktu darinya digunakan untuk mengevaluasi dirinya." (Kholiq, 1999: 21).

\section{Relevansi Pemikiran al-Ghazali dengan Pendidikan Saat Ini}

Konsep pendidikan al-Ghazali sebegaimana dipaparkan sebelumnya sebenarnya masih relevan untuk pendidikan Islam saat ini, tetapi masih belum maksimal diterapkan. Dari sisi pendidik, alGhazali menekankan bahwa seorang pendidik itu jangan mengharapkan upahnya akan tetapi kemanfaatan ilmunya pada muridnya. Hal ini bukan berarti seorang pendidik tidak memerlukan materi. Namun, di sini dapat diartikan bahwa materi yang dihasilkan oleh pendidik tersebut adalah buah dari keikhlasannya dalam menyampaikan ilmunya. Sehingga jikalau saat ini ditemukan banyak pendidik yang menikmati kemewahannya, bisa berarti mereka telah sampai pada tingkat keikhlasan yang tinggi.

Selanjutnya dilihat dari aspek peserta didiknya, al-Ghazali menghendaki seorang peserta didik yang menjaga perilakunya terhadap guru atau pendidiknya, serta terhadap temannya. Namun, saat ini bisa dilihat banyak tawuran yang terjadi antar pelajar, murid yang menghina gurunya dan lain sebagainya. Sehingga sekarang ini pendidikan moral (karakter) diterapkan dalam konsep kurikulumnya.

Adapun mengenai metode riyâdlah, mujâhadah, maupun hukuman dan pujian masih sangat efektif untuk diterapkan di sekolah- 
sekolah saat ini. Pengajaran secara bertahap (gradasi) juga sesuai dengan pendidikan di Indonesia saat ini, bahwa pendidikan yang diberikan pada peserta didik harus sesuai dengan perkembangannya, baik aspek psikologis, maupun kognitifnya. Seperti pengajaran di PAUD (Pendidikan Anak Usia Dini) belum saatnya untuk membaca, menulis, maupun menghitung, akan tetapi baru mulai untuk diperkenalkan saja. Hal ini sejalan dengan pemikiran dari al-Ghazali. Pemikiran pendidikan al-Ghazali ini paling baik, sistematis, dan komprehensif dibandingkan dengan tokoh-tokoh yang lain. Hal ini disebabkan al-Ghazali adalah seorang guru besar yang juga sekaligus pemikir besar. Pemikiran pendidikan al-Ghazali telah mendominasi atmosfer pemikiran pendidikan selama berabad-abad semenjak kematiannya (Sudarsono, 1997: 39).

\section{Kesimpulan}

Dari kajian sederhana dalam pembahasan tulisan ini, dapat ditarik kesimpulan bahwa al-Ghazali merupakan seorang pemikir yang luar biasa. Ia telah menghasilkan konsep pendidikan yang berorientasi pada kebahagiaan manusia, baik di dunia maupun di akhirat. Ia mempunyai kecenderungan religius sofistis yang lebih mementingkan ilmu-ilmu agama, tetapi juga tidak serta merta meninggalkan ilmu-ilmu non-agama yang berkontribusi untuk kemaslahatan manusia pada umumnya. Pemikirannya tersebut masih relevan untuk pendidikan Islam saat ini, dan seharusnya dapat dipergunakan secara maksimal. Al-Ghazali tidak semata-mata menempatkan pendidikannya berpusat hanya pada ilmu dunia saja akan tetapi berkesinambungan dengan ilmu akhirat. 


\section{DAFTAR PUSTAKA}

Abdullah, Amin. 2002. Antara al-Ghazali dan Kant: Filsafat Etika Islam. Bandung: Mizan.

Abidin, Ibnu. 1998. Pemikiran al-Ghazali tentang Pendidikan. Yogyakarta: Pustaka Pelajar.

Ali, Shafique. 2005. Filsafat Pendidikan al-Ghazali: Gagasan Konsep Teori dan Filsafat Ghazali Mengenai Pendidikan, Pengetahuan, dan Belajar. Bandung: Pustaka Setia.

Al-Rasyidi. 2005. Filsafat Pendidikan Islam. Jakarta: PT Ciputat Press Group.

Arifin, Muzayyin. 2005. Filsafat Pendidikan Islam. Jakarta: Bumi Aksara.

Azra, Azyumardi. 1998. Esei-esei Intelektual Muslim dan Pendidikan Islam. Jakarta: Logos Wacana Ilmu.

Basri, Hasan. 2009. Filsafat Pendidikan Islam. Bandung: Pustaka Setia.

Daudy, Ahmad. 1989. Kuliah Filsafat Islam. Jakarta: PT. Bulan Bintang.

Kholiq, Abdul. 1999. Pemikiran Pendidikan Islam Kajian Tokoh Klasik \& Kontemporer. Yogyakarta: Fakultas Tarbiyah IAIN Walisongo Semarang bekerjasama dengan Pustaka Pelajar.

Kurniawan, Irwan. 2003. Al-Ghazali. Mutiara Ihya' 'Ulumuddin: Ringkasan yang Ditulis Sendiri Oleh Sang Hujjatul Islam. Bandung: Mizan.

Kurniawan, Syamsul. 2011. Jejak Pemikiran Tokoh Pendidikan Islam. Yogyakarta: Ar-Ruzz Media.

Nakosteen, Mehdi. 1996. Kontribusi Islam atas Dunia Intelektual Barat. Surabaya: Risalah Gusti.

Nata, Abuddin. 2000. Pemikiran Para Tokoh Pendidikan Islam: Seri Kajian Filsafat Pendidikan Islam. Jakarta: PT. Raja Grafindo Persada.

Nizar, Samsul. 2002. Filsafat Pendidikan Islam: Pendekatan Historis, Teoritis dan Praktis. Jakarta: Ciputat Pers. 
Qardhawi, Yusuf. 1997. Pro Kontra Pemikiran al-Ghazali. Surabaya: Risalah Gusti.

Ramayulis. 2005. Ensiklopedi Tokoh Pendidikan Islam. Jakarta: PT Ciputat Press Group.

Shihab, Umar. 2008. Kontekstualitas Al-Qur'an: Kajian Tematik Atas Ayat-ayat Hukum Dalam Al-Qur'an. Jakarta: Penamadani.

Soleh, Khudlori. 2009. Skeptisisme al-Ghazali. Malang: UIN Malang Press.

Sudarsono. 1997. Filsafat Islam. Jakarta: PT Rineka Cipta.

Sudjana, Nana. 1991. Pembinaan dan Pengembangan Kurikulum di Sekolah. Bandung: Sinar Baru Al Gensindo.

Suwito. 2005. Sejarah Sosial Pendidikan Islam. Jakarta: Prenada Media Kencana.

Umam, Cholil. 1996. Ikhtisar Ilmu Pendidikan Islam. Surabaya: Duta Aksara.

Zaqzuq, Mahmud. 1987. Al-Ghazali Sang Sufi Sang Filosof. Bandung: Pustaka. 